\title{
Role of pentoxifylline and iloprost in the prevention of ischemia-reperfusion injury in an experimental model of intestine ischemia-reperfusion in rats
}

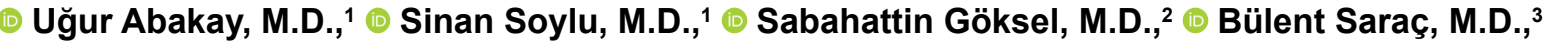 \\ ๑1 Zeynep Deniz Şahin İnan, M.D., ${ }^{4}$ ¿ Erol Çakmak, M.D., ${ }^{5} \odot$ Özge Korkmaz, M.D., ${ }^{2}$

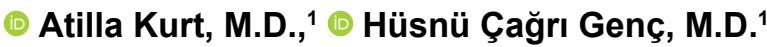

${ }^{1}$ Department of General Surgery, Cumhuriyet University Faculty of Medicine, Sivas-Turkey

${ }^{2}$ Department of Cardiovasculer Surgery, Cumhuriyet University Faculty of Medicine, Sivas-Turkey

${ }^{3}$ Department of Pharmacology, Cumhuriyet University Faculty of Medicine, Sivas-Turkey

${ }^{4}$ Department of Histology, Cumhuriyet University Faculty of Medicine, Sivas-Turkey

${ }^{5}$ Department of Gastroenterolgy, Cumhuriyet University Faculty of Medicine, Sivas-Turkey

\begin{abstract}
BACKGROUND: Intestinal ischemia-reperfusion (I/R) injury can lead to multiple organ failure and death. The aim of this study was to investigate the effects of pentoxifylline and iloprost administered before reperfusion in intestinal ischemia.

METHODS: In total, 25 male Wistar Albino rats weighing 250-300 g were divided into five groups each comprising five subjects: control group $(n=5)$, sham group $(n=5$, no I/R), I/R group $(n=5,45 \mathrm{~min}$ ischemia, and 120 min reperfusion), I/R + pentoxifylline group $(n=5,45 \mathrm{~min}$ ischemia following intraperitoneal $50 \mathrm{mg} / \mathrm{kg}$ pentoxifylline and $120 \mathrm{~min}$ reperfusion), and I/R + iloprast group ( $\mathrm{n}=5,45 \mathrm{~min}$ ischemia followed by intraperitoneal $2 \mathrm{mcg} / \mathrm{kg}$ iloprost and $120 \mathrm{~min}$ reperfusion). At the end of the experiment, ileum specimens were stained using hematoxylin-eosin and histopathologically evaluated using the Chiu score. Isometric contraction-relaxation responses were recorded using organ baths for contraction-relaxation responses.
\end{abstract}

RESULTS: Pentoxifylline provided a significant improvement in response to histopathological and contraction-relaxation responses. Although iloprost provided recovery in reperfusion injury, it was not statistically significant.

CONCLUSION: Our findings demonstrate that pentoxifylline may be promising in preventing small bowel ischemia-reperfusion injury. We concluded that further clinical and experimental studies for iloprost are needed.

Keywords: Acute mesenteric ischemia; iloprost; ischemia-reperfusion injury; pentoxifylline.

\section{INTRODUCTION}

Acute mesenteric ischemia (AMI) is a fatal vascular pathology with mortality ranging from $50 \%$ to $80 \%{ }^{\left[{ }^{[}\right]}$Small intestinal ischemia occurs due to intravascular reasons such as arterial thrombosis, embolism, Henoch-Schonlein purpura, disseminated intravascular coagulation or external pressure on vessels, including volvulus, invagination, incarcerated inguinal hernia, tumor and fibrotic band. ${ }^{[2]}$ Delayed diagnosis, comorbidities, and ischemia-reperfusion (I/R) are associated with poor prognosis. ${ }^{[3]}$ Long periods of ischemia result in cellular damage and death. Reperfusion leads to the release of free oxygen radicals that accelerate tissues deteriotion This is known as reperfusion injury. ${ }^{[1]}$ Therefore, it is critical reduce

Cite this article as: Abakay U, Soylu S, Göksel S, Saraç B, Şahin İnan ZD, Çakmak E, et al. Role of pentoxifylline and iloprost in the prevention of ischemia-reperfusion injury in an experimental model of intestine ischemia-reperfusion in rats. Ulus Travma Acil Cerrahi Derg 2018;24:398-404.

Address for correspondence: Sinan Soylu, M.D.

Cumhuriyet Üniversitesi Tıp Fakültesi, Genel Cerrahi Anabilim Dalı, 58140 Sivas, Turkey

Tel: +90 346 - 219 II 56 E-mail: soylu.sinan@hotmail.com

Ulus Travma Acil Cerrahi Derg 2018;24(5):398-404 DOI: 10.5505/tjtes.2018.22227 Submitted: 04.01.2018 Accepted: 12.03.2018 Online: 28.09.2018

Copyright 2018 Turkish Association of Trauma and Emergency Surgery 
the duration of ischemia with early diagnosis and appropriate treatment methods and reduce the damage that occurs during the reperfusion period to minimum. ${ }^{[4,5]}$

Both pentoxifylline (PTX) and iloprost have been used in peripheral vascular diseases for many years, and the results are satisfactory. ${ }^{[4,5]}$

PTX has varying effects on providing cell membrane fluidity, immunomodulation, stimulation of fibrinolysis, anticoagulation, and fibroblast physiology. ${ }^{[4,6]}$ Some studies have shown that PTX therapy reduces cardiac output, improves liver perfusion and intestinal blood flow after bleeding and post-resuscitation, and has an important effect in improving ischemic conditions in colon anastomoses. ${ }^{[7-9]}$ Additionally, it has been reported to reduce oxidative stress and inflammatory indices by suppressing the production of tumor necrosis factor- $\alpha$ and interleukins (IL-I, IL-6, and IL-I0). ${ }^{[10]}$

lloprost is frequently used in the treatment of diabetic foot, pulmonary arterial hypertension and peripheral vascular disease, such as Burger's disease. ${ }^{\left[{ }^{\prime I}\right]}$ It is a potent vasodilator and a member of the prostacyclin analog group, which has antiplatelet, anti-proliferative and anti-inflammatory properties. It can alter the endothelial prostaglandine 12/ thromboxane $\mathrm{A} 2\left(\mathrm{PGI}_{2} / \mathrm{TXA}_{2}\right)$ ratio in favor of prostacyclin. ${ }^{[12]}$

lloprost is currently being used in patients with peripheral vascular disease, especially those with chronic ischemic chest pain. It acts by increasing nitric oxide synthase in the vascular tissue. It is believed that this pathway may be effective in I/R injury in the intestine. ${ }^{[13]}$ Therefore, iloprost application was planned in this study.

In this study, we aimed to evaluate the effects of PTX and iloprost in an I/R model of the mesenteric artery of rats. We evaluated the contraction - relaxation responses and pathological specimens in the small intestine segments.

\section{MATERIALS AND METHODS}

This experimental study was conducted between September 2016-November 2016 in the Cumhuriyet University experimental animal laboratory. The study protocol was approved by the Local Ethics Committee (Date/number: 04,08,2016/050-04-04-78).

A total of 25 Wistar Albino male rats weighing 250-300 g were used in this study. The rats were kept in wire cages in a $12 \mathrm{~h}$ light/dark cycle at room temperature and fed with standard rat diet and water. They were allowed to drink only water for $12 \mathrm{~h}$ before surgery. The rats were, then, randomly divided into five groups as follows: control, sham, I/R, I/R treated with $50 \mathrm{mg} / \mathrm{kg}$ PTX administered intraperitoneally (Trental ${ }^{\circledR}$; Sanofi Aventis Pharma, Istanbul, Turkey) (I/R + PXT) and I/R treated with $20 \mu \mathrm{g} / \mathrm{mL}$ iloprost administered in- traperitoneally (llomedin ${ }^{\circledR}, 20 \mu \mathrm{g} / \mathrm{mL}$, Bayer Schering Pharma; Bayer Turk Kimya San. Ltd. Sti, Umraniye, Istanbul, Turkey) $(I / R+I L P)$. No death was observed during the study.

Rats were anesthetized by subcutaneous injection of ketamine (90 mg/kg; Ketalar ${ }^{\circledR}$; Parke-Davis, Istanbul, Turkey) and xylazine (3 mg/kg Rompun ${ }^{\circledR}$; Bayer, Istanbul, Turkey). After anesthesia was induced, laparotomy was performed with an abdominal midline incision. The intestines were moved to the body surface, and the superior mesenteric artery (SMA) was dissected after cutting the Treitz ligament. Following laparotomy, ileum resection was performed in the control group. The rats in the sham group were monitored until the end of the experiment after the demonstration of SMA. A 45-min ischemia was established with the compression of the SMA from the exit site of the aorta by an atraumatic microvascular clamp in the I/R groups. Adequate occlusion was confirmed by the absence of pulsation in the mesenteric vessels and paleness. The clamp was removed at the end of $45 \mathrm{~min}$ and reperfusion was provided for $120 \mathrm{~min}$. During the waiting periods, the abdomen was closed using wet and sterile tampons. lleum resection was performed for pathological examination and isometric contraction responses in the test animals. At the end of the study, the rats were euthanized using a high dose of pentothal sodium.

The tissues of ileum were fixed at $10 \%$ buffered formaldehyde, and sections with a thickness of $5 \mu \mathrm{m}$ were obtained. The sections were, then, stained using Hematoxylin \& Eosin and were examined under a light microscope (Olympus BX5I Tokyo, Japan). Histopathological evaluations of the intestinal sections were performed according to the scoring system defined by Chiu et al. and the mucosal lesions were graded between 0 and 5 (Table I). ${ }^{[14]}$

Resected ileum segments were placed into Krebs bicarbonate solution. Then, they were incubated at $4^{\circ} \mathrm{C}$ for $4 \mathrm{~h}$. This

Table I. Chiu scoring system ${ }^{[14]}$

\begin{tabular}{ll}
\hline Grade & Characteristics \\
\hline 0 & $\begin{array}{l}\text { Mucosa with normal villi } \\
\text { Development of the sub-epithelial Gruenhagen's space, } \\
\text { usually at the villus apex, frequently associated with } \\
\text { capillary congestion }\end{array}$ \\
2 & $\begin{array}{l}\text { Extension of the sub-epithelial space with moderate } \\
\text { lifting of the epithelial layer from the lamina propria }\end{array}$ \\
3 & $\begin{array}{l}\text { Massive epithelial lifting down the sides of the villi } \\
\text { Denuded villi with lamina propria and dilated } \\
\text { capillaries exposed } \\
\text { Increased cellularity of lamina propria may be noted } \\
\text { Digestion and disintegration of lamina propria; } \\
\text { hemorrhage and ulceration }\end{array}$ \\
\hline
\end{tabular}


Table 2. $E_{\max }$ and $\mathrm{pD}_{2}$ values of contraction responses to histamine, carbachol and substance $\mathrm{p}$ of tissues

\begin{tabular}{|c|c|c|c|}
\hline Grups & Contraction to histamine & Contraction to carbachol & Contraction to substance $p$ \\
\hline \multicolumn{4}{|l|}{ Control } \\
\hline $\mathrm{E}_{\max }$ & $120.62 \pm 8.13$ & $141.57 \pm 5.99$ & $84.44 \pm 6.13$ \\
\hline $\mathrm{pD}_{2}$ & $6.31 \pm 0.35$ & $6.36 \pm 0.29$ & $6.34 \pm 0.33$ \\
\hline \multicolumn{4}{|l|}{ Sham } \\
\hline $\mathrm{E}_{\text {max }}$ & $117.67 \pm 6.16$ & $128.69 \pm 7.10$ & $77.98 \pm 6.02$ \\
\hline $\mathrm{pD}_{2}$ & $6.37 \pm 0.27$ & $6.25 \pm 0.30$ & $6.31 \pm 0.29$ \\
\hline \multicolumn{4}{|c|}{ Ischemia/Reperfusion } \\
\hline $\mathrm{E}_{\max }$ & $35.65 \pm 6.02^{+}$ & $45.75 \pm 7.03^{+}$ & $24.22 \pm 7.30^{+}$ \\
\hline $\mathrm{pD}_{2}$ & $6.22 \pm 0.31$ & $6.4 I \pm 0.3 I$ & $6.40 \pm 0.29$ \\
\hline \multicolumn{4}{|c|}{ Pentoxifylline + Ischemia/Reperfusion } \\
\hline $\mathrm{E}_{\max }$ & $81.00 \pm 5.93^{*}$ & $91.09 \pm 5.98^{*}$ & $56.65 \pm 6.01^{*}$ \\
\hline $\mathrm{pD}_{2}$ & $6.25 \pm 0.26$ & $6.33 \pm 0.28$ & $6.30 \pm 0.31$ \\
\hline \multicolumn{4}{|c|}{ Iloprost + Ischemia/Reperfusion } \\
\hline $\mathrm{E}_{\max }$ & $41.98 \pm 5.72^{+}$ & $49.87 \pm 6.50^{+}$ & $29.12 \pm 6.03^{+}$ \\
\hline $\mathrm{pD}_{2}$ & $6.4 I \pm 0.32$ & $6.36 \pm 0.29$ & $6.28 \pm 0.34$ \\
\hline
\end{tabular}

*Significantly lower than control and sham operation groups, significantly higher than ischemia reperfusion and iloprost + ischemia reperfusion groups $(p<0.05)$. ${ }^{+}$Significantly lower than control, sham and PTX + ischemia reperfusion groups $(p<0.05)$.

procedure was done to equilibrate the contractions and stabilize the subsequent contractile responses to carbachol and substance $p$. Thereafter, the ileum segments were placed into the Krebs bicarbonate solution specific for the ileum, with a temperature set at $37^{\circ} \mathrm{C}$ and aerated with $95 \% \mathrm{O}_{2}$ and $5 \% \mathrm{CO}_{2}$, to determine the spontaneous contraction responses (amplitude and frequency) for each group (content: as $\mathrm{mmol} / \mathrm{L}$; sodium chloride, 120; potassium chloride, 4.6; calcium chloride, 2.5; magnesium chloride, I.2; sodium bicarbonate, 22; sodium phosphate monobasic and glucose, II.5). The ileal segments were connected to the transducer (Grass FT 03, Quincy Mass., USA) and recorded using a polygraph (Grass 79 E, Quincy Mass., USA) to measure isometric contractions.

Contraction was initially achieved through the administration of $80 \mathrm{mmol} / \mathrm{L} \mathrm{KCl}$, and contraction responses to histamine $\left(10^{-9}-10^{-4} \mathrm{~mol} / \mathrm{L}\right)$, carbachol $\left(10^{-9}-10^{-4} \mathrm{~mol} / \mathrm{L}\right)$ and substance $\mathrm{P}\left(10^{-9}-10^{-4} \mathrm{~mol} / \mathrm{L}\right)$ were examined to see receptor-mediated responses of tissues, and these contraction responses were expressed as percentages (\%) of contractions with $\mathrm{KCl}$. The maximal contraction responses $\left(\mathrm{E}_{\max }\right)$ of the tissues and the negative logarithm values of half of the maximal contraction concentration $\left(\mathrm{pD}_{2}\right)$ were calculated (Table 2 ).

\section{Statistical Analysis}

Statistical analysis was performed using the Statistical Package for Social Sciences (SPSS), version 16.0, software (SPSS Inc., Chicago, IL, USA). Descriptive data were expressed as mean + standard error of the mean. Analysis of variance was used for the initial analysis, and the Newman Keuls test was used as the post-hoc test. A p value of $<0.05$ was considered statistically significant.

\section{RESULTS}

In the histopathological evaluation, a usual appearance of the villi was observed in the tunica mucosa layer in the sham group. The epithelium surrounding the villi was regular and the lamina propria of the tunica mucosa was appropriately positioned. In the I/R group, the loss of villi and occasional dilated capillaries with the disruption of the integrity of lamina propria were observed. In the IL group, in addition to loss of villi and disruption of integrity of lamina propria, intensive bleeding sites and inflammatory cells were observed. Compared to the I/R group, although there were more bleeding sites in the lamina propria, the villi were not completely ruptured and the lamina propria on the base of the villi was regular. In the PTX group, occasional loss of villi and regular lamina propria layer were observed. Also, compared to the iloprost groups, less epithelial loss, more regular lamina propria and villus structure was observed (Fig. I).

When Chiu scores of the groups were compared; the lowest score was in the control group and then in the sham, PTX, iloprost groups, respectively, and the highest in the I/R group. In the PTX group, the Chiu score was significantly higher than the control and sham groups $(p=0.023)$, and was significantly lower than the $I / R$ and iloprost groups $(p=0.005, p=0.004$; Fig. 2). 

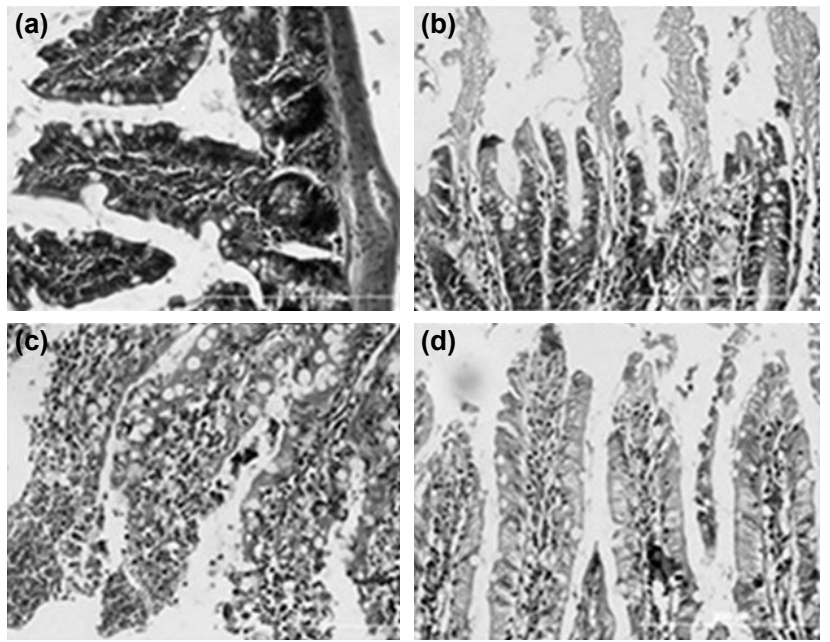

Figure 1. Histopathological images of biopsy samples obtained from the ileum ( $\times 40$, hematoxylin-eosin). (a) Sham group (40X): Intestinal layers with $0-1$ degrees of injury are shown. Normal-looking villus is observed in the tunica mucosa layer. The epithelium that surrounds the villi was regular and lamina propria of the tunica mucosa was in an appropriate location. (b) I/R group (40X): The villi with $2-5$ degrees of injury are shown with great magnification. Intensive cell loss in epithelial cells of villus, dense blood vessels in lamina propria are seen. (c) lloprost group (40X): The villi with 2 -3 degrees of injury are shown with great magnification. The loosing of the villi surrounding the epithelium and the intense dilated blood vessels in the lamina propria are seen. (d) PTX group (40X): The intestinal layers with $1-2$ degrees of injury are shown. Loss of villi and regular lamina propria layer are seen.

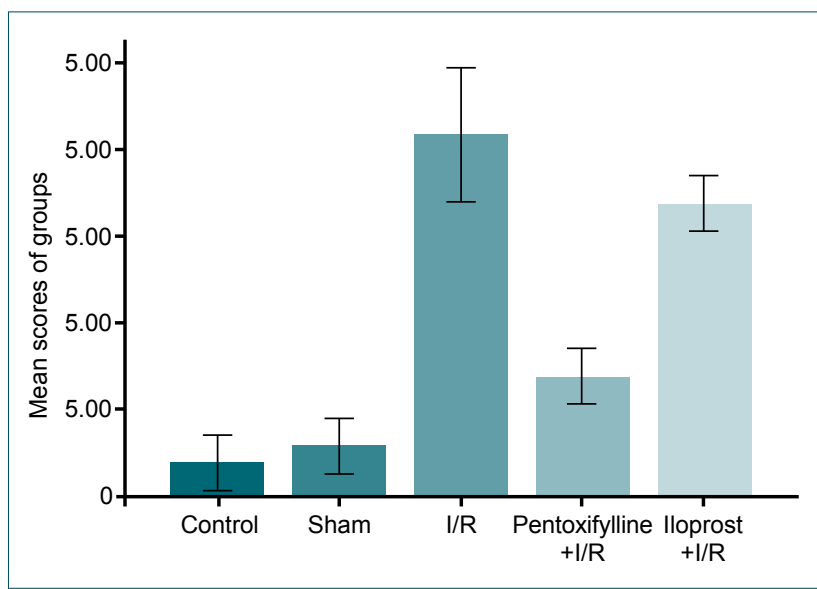

Figure 2. Mean scores of groups according to Chiu scoring. There is a statistically significant difference of the control and sham groups among other groups $(p<0.005)$. There is a statistically significant difference between PTX + I/R group and I/R and iloprost + I/R groups $(p<0.005)$. There is no significant difference between the I/R and iloprost I/R groups ( $p>0.05$ ).

When responses of the groups were examined: The spontaneous contractions in both amplitude and frequency of the control group were observed to be the highest. Although spontaneous contraction responses in the sham group were slightly less than those in the control group, there was no significant difference between two groups ( $>0.05)$. Spon- taneous contractions in both amplitude and frequency in the I/R group were significantly decreased, compared to the control and sham groups $(p<0.05)$. Spontaneous contraction responses were significantly improved in the I/R group, compared to I/R alone ( $p<0.05$; Fig. 3).

There was no significant difference between the groups in terms of response to $80 \mathrm{mmol} / \mathrm{L} \mathrm{KCl}(p>0.05)$. The highest contraction responses in terms of receptor-mediated responses were in the tissues of the control group. In the tissues of I/R group, the receptor-mediated responses had least contractions for all three drugs (histamine, carbachol and substance $-p)$. The contraction responses obtained from the I/R group treated with iloprost were similar to those of the I/R alone group $(p>0.05)$. Although the response of tissues treated with PTX was not satisfactorycompared to the control and sham groups for all three drugs, it was significantly higher than the groups treated with iloprost and I/R alone ( $p<0.05 ;$ Fig. 4). The $\mathrm{E}_{\max }$ and $\mathrm{pD}_{2}$ values of the contraction responses of the three drugs in the five groups are shown in Table 2.

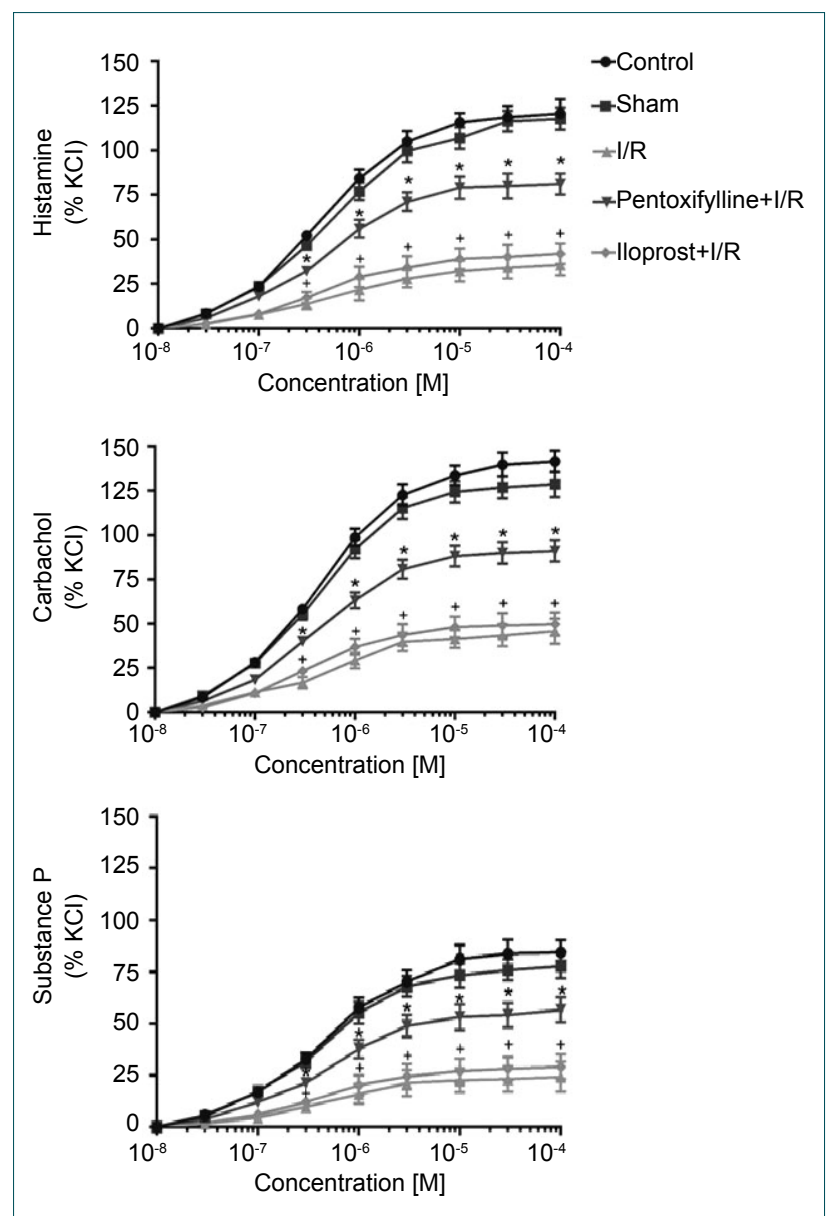

Figure 3. Amplitude and frequencies of spontaneous contractions. *Significantly lower than the control and sham operation groups $(p<0.05)$. ${ }^{a}$ Significantly lower than the control and sham operation groups, and significantly higher than ischemia reperfusion and iloprost $+\mathrm{I} / \mathrm{R}$ groups $(p<0.05)$. ${ }^{\beta}$ Significantly lower than the control and sham operation groups $(p<0.05)$. 


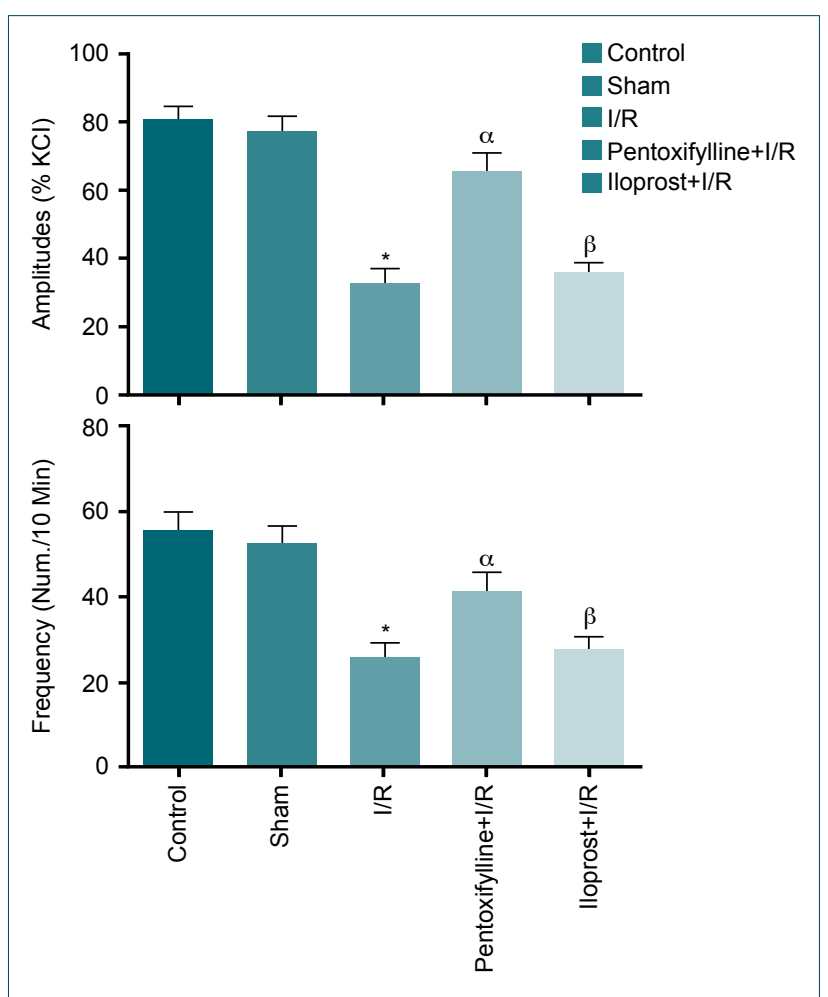

Figure 4. Contraction responses of tissues to histamine, carbachol and substance $-\mathrm{p}$ (\% of $\mathrm{KCl}$ contractions). *Significantly lower than the control and sham operation groups, significantly higher than I/R and iloprost $+\mathrm{l} / \mathrm{R}$ groups $(\mathrm{p}<0.05)$. ${ }^{+}$Significantly lower than control, sham operation and PTX + ischemia reperfusion groups $(p<0.05)$.

\section{DISCUSSION}

The first finding of our study was that PTX reduced the histopathological damage and improved contraction -relaxation responses in the ileum segments in the intestinal $I / R$ injury, but the same effects were not observed with iloprost treatment.

AMI is a clinical condition that may progress to multi-organ failure and is associated with high mortality and morbidity rates following acute vascular insufficiency. ${ }^{[15]}$ An ischemia lasting less than $20 \mathrm{~min}$ in the small intestines does not significantly change the mucosa, while an ischemia lasting longer than $2 \mathrm{~h}$ may cause permanent damage and even transmural necrosis. ${ }^{[16]}$ Intestinal ischemia and reperfusion lead to the formation of inflammatory cytokines and free oxygen radicals. [17] Cytotoxic events cause toxic products to cross the systemic circulation by impairing the barrier function of the gut, and result in multi-organ failure by affecting the kidneys, liver, and heart and, the regional tissues and lung particularly. ${ }^{[18]}$

PTX inhibits the enzyme phosphodiesterase. It exerts its therapeutic effects by increasing the blood flow and tissue oxygenation. ${ }^{[19]}$ Although it leads to an increase in primary cardiac output and a decrease in the total systemic vascular resistance with systemic vasodilatation, it does not lead to a significant change in the systemic arterial pressure. In addi- tion, it results in a decrease in the resistance to blood flow by increasing erythrocyte flexibility which decreases the total blood viscosity. ${ }^{[14]}$ Also, it has been reported that PTX inhibits the production of pro-inflammatory cytokines and has anti-inflammatory features and protects the mitochondrial structures of the cells. ${ }^{[20]}$ Therefore, it is widely used in the medical treatment of peripheral arterial diseases. ${ }^{[4,5,10]}$

Prostaglandins are biologically active mediators released from endothelial cells, smooth muscles, pericytes, fibroblasts, mast cells, leukocytes, and platelets. They have vasoactive functions that are thought to be important in an I/R injury. PGI2 is an unstable metabolite that increases cyclic-adenosine monophosphate concentration in the vascular smooth muscle, ${ }^{[21]}$ inhibits platelet aggregation, and leads to vasodilatation. ${ }^{[22]}$ Iloprost is a stable PGI2 analog and is widely used in the treatment of pathologies such as diabetic foot, peripheral arterial disease, venous ulcers and Raynaud's phenomenon. [5] We aimed to compare the consequences of PTX and ilioprost on mesenteric ischemia due to these effects.

Different models were formed to generate experimental I/R injury. In a study, Mallick et al. ${ }^{[23]}$ generated experimental models by performing $30 \mathrm{~min}$ of ischemia and $120 \mathrm{~min}$ of reperfusion, while Arruda et al. ${ }^{[24]}$ determined their injury model as $45 \mathrm{~min}$ of ischemia and $120 \mathrm{~min}$ of reperfusion. In our study, we performed $45 \mathrm{~min}$ of ischemia and $120 \mathrm{~min}$ of reperfusion. We achieved an effective existing I/R model.

In our study, $50 \mathrm{mg} / \mathrm{kg}$ PTX and I $\mu \mathrm{g} / \mathrm{kg}$ iloprost were administered intraperitoneally to the experimental groups during the period of reperfusion for $120 \mathrm{~min}$ after $45 \mathrm{~min}$ of ischemia, and ileum resection was performed. In a similar study conducted by Savaş et al., ${ }^{[25]}$ PTX was administered intraperitoneally at a dose of $50 \mathrm{mg} / \mathrm{kg}$ before $15 \mathrm{~min}$ of ischemia induction. They found that the injury was significantly reduced in the PTX group, compared to the control group. However, they found that PTX reduced mucosal injury, but did not normalize. In our study, PTX was given during the reperfusion phase, which is more realistic in practice. Because of patients with AMI were usually admit with in ischemic phase and during the treatment period was provided reperfusion.

Our results demonstrated that PTX treatment reduced I/R injury. Histopathological results and contraction -relaxation responses were improved in this treatment. These results were statistically significant and, consistent with literature.

In literature several iloprost studies have shown that antiinflammatory parameters decreased in the I/R injury condition. ${ }^{[26-28]}$ In our study, we did not evaluate the measured anti-inflammatory parameters but histopatological results and contraction relaxation responses of the intestinal tissues were observed in the iloprost group. Although the results were better than the I/R group, it was not statistically significant. 


\section{Limitations}

There were some limitations in this study. Evaluation of the superoxygen radicals and total anti-oxidant capacity which are effective I/R injury, could give clearer results. These parameters could not be measured because the laboratory conditions were not suitable. Futures studies in this regard are needed.

\section{Conclusions}

Our study is the first study to investigate the effects of administration of PTX and iloprost on the injury after $I / R$ by comparing the histology and contraction-relaxation responses. Elderly patients with widespread atherosclerosis, diabetes, atrial fibrillation and many other risk factors are at risk for mesenteric artery embolism or thromboembolism. In this group of patients, with the establishment of diagnosis, giving PTX may recover the remaining intestinal tissue with less injury from reperfusion. The same effects may not be provided with iloprost. However, there is a need for more detailed experimental studies on this subject.

\section{Funding: None}

Acknowledgements: The authors declare that this study has received no financial support.

\section{Conflict of interest: None declared.}

\section{REFERENCES}

1. Berland T, Oldenburg WA. Acute mesenteric ischemia. Curr Gastroenterol Rep 2008;10:341-6. [CrossRef]

2. Polat H, Türk Ö, Yaşar B, Uysal O. The effect of ligustrazin in intestinal ischemia reperfusion injury generated on rats [Article in Turkish]. Ulus Travma Acil Cerrahi Derg 2015;21:163-7.

3. Cotran, RS, Kumar V, Robbins SL, Lesão e morte celular. In: Robbins, editor. Patologia estrutural e funcional. 5 th ed. Rio de Janeiro: Guanabara Koogan; 1996. p. 1-30.

4. Paradowski, PT, Zeman, K. Pentoxifylline [Article in Polish]. Post Hig Med Doswiad 1995;49:201-20.

5. Altstaedt HO, Berzewski B, Breddin HK, Brockhaus W, Bruhn HD, Cachovan M, et al. Treatment of patients with peripheral arterial occlusive disease Fontaine stage IV with intravenous iloprost and PGE1: a randomized open controlled study. Prostaglandins Leukot Essent Fatty Acids 1993;49:573-8. [CrossRef]

6. Müller R. Hemorheology and peripheral vascular diseases: a new therapeutic approach. J Med 1981;12:209-36.

7. Ribeiro EA, Poli-de-Figueiredo LF, Vincenzi R, Galvao FH, Margarido N, Rocha-E-Silva M, et al. Intraportal versus Systemic Pentoxifylline Infusion after Normothermic Liver Ischemia: Effects on Regional Blood Flow Redistribution and Hepatic Ischemia-Reperfusion Injury. HPB Surg 2013;2013:689835. [CrossRef]

8. Cruz RJ Jr, Yada-Langui MM, de Figueiredo LF, Sinosaki S, Rocha e Silva M. The synergistic effects of pentoxifylline on systemic and regional perfusion after hemorrhage and hypertonic resuscitation. Anesth Analg. 2006;102:1518-24. [CrossRef]

9. Luo M, Dong L, Li J, Wang Y, Shang B. Protective effects of pentoxifylline on acute liver injury induced by thioacetamide in rats. Int J Clin Exp Pathol 2015;8:8990-6.
10. Oliveira TRR, Oliveira GF, Simóes RS, Tikazawa EH, Monteiro HP, Fagundes DJ, et al. The role of ischemic preconditioning and pentoxifylline in intestinal ischemia/reperfusion injury of rats. Acta Cir Bras 2017;32:559-67. [CrossRef]

11. Senol S, Senol A. Investigation of Asymmetric and Symmetric Dimethylarginine Levels after Iloprost Treatment in Patients with Buerger's Disease. Eur J Vasc Endovasc Surg 2017;53:439-42. [CrossRef]

12. Gomberg-Maitland, M, Olschewski H. Prostacyclin therapies for the treatment of pulmonary arterial hypertension. European Respir J 2008;31:891-901. [CrossRef]

13. Misırlığlu G, Hüseyin S, Yüksel V, Güçlü O, Karadağ H, Canbaz S, et al. In vitro effects of prostaglandin E1, prostaglandin I2 and papaverine on internal thoracic artery graft [Article in Turkish]. Turk Gogus Kalp Dama 2015;23:463-6. [CrossRef]

14. Ehrly AM. The effect of pentoxifylline on the deformability of erythrocytes and on the muscular oxygen pressure in patients with chronic arterial disease. J Med 1979;10:331-8.

15. Aguilar-Nascimento JE, Salomão AB, Nochi RJ Jr, Nascimento M, Neves Jde S. Intraluminal injection of short chain fatty acids diminishes intestinal mucosa injury in experimental ischemia-reperfusion. Acta Cir Bras 2006;21:21-5. [CrossRef]

16. Park PO, Haglund U, Bulkley GB, Fält K. The sequence of development of intestinal tissue injury after strangulation ischemia and reperfusion. Surgery 1990;107:574-80.

17. Clark ET, Gewertz BL. Intermitant ischemia potentiates intestinal reperfusion injury. J Vasc Surg 1991;13:601-6. [CrossRef]

18. Köksoy C, Kuzu MA, Kuzu I, Ergün H, Gürhan I. Role of tumour necrosis factor in lung injury caused by intestinal ischaemia-reperfusion. $\mathrm{Br} \mathrm{J}$ Surg 2001;88:464-8. [CrossRef]

19. Foster ME, Laycock JR, Silver IA, Leaper DJ. Hypovolaemia and healing in colonic anastomoses. Br J Surg 1985;72:831-4. [CrossRef]

20. Gómez-Cambronero L, Camps B, de La Asunción JG, Cerdá M, Pellín A, Pallardó FV, et al. Pentoxifylline ameliorates cerulein-induced pancreatitis in rats: role of glutathione and nitric oxide. J Pharmacol Exp Ther 2000;293:670-6.

21. Kadowitz PJ, Chapnick BM, Feigen LP, Hyman AL, Nelson PK, Spannhake EW. Pulmonary and systemic vasodilator effects of the newly discovered prostaglandin, PGI2. J Appl Physiol Respir Environ Exerc Physiol 1978;45:408-13. [CrossRef]

22. Mulvin D, Jones K, Howard R, Grosso M, Repine J, Johnston M. The effect of prostacyclin as a constituent of a preservation solution in protecting lungs from ischemic injury because of its vasodilatory properties. Transplantation 1990;49:828-30. [CrossRef]

23. Mallick IH, Yang W, Winslet MC, Seifalian AM. Ischemia-reperfusion injury of the intestine and protective strategies against injury. Dig Dis Sci 2004;49:1359-77. [CrossRef]

24. de Arruda MJ, Poggetti RS, Fontes B, Younes RN, Souza AL Jr, Birolini D. Intestinal ischemia/reperfusion induces bronchial hyperreactivity and increases serum TNF-alpha in rats. Clinics (Sao Paulo) 2006;61:21-8.

25. Savaş C, Aras T, Cakmak M, Bilgehan A, Ataoğlu O, Türközkan N, et al. Pentoxifylline inhibits overflow and reduces intestinal reperfusion injury. J Pediatr Surg 1997;32:905-10. [CrossRef]

26. Wei W, Wei FC, Hung LM. Diazoxide ameliorates microcirculatory disturbances through PKC-dependent pathway in I/R-injured rat cremaster muscles. J Biomed Sci 2005;12:521-9. [CrossRef]

27. Katırcıoğlu SF, Saritaş Z, Ulus AT, Yamak B, Yücel D, Ayaz S. Iloprost added to the cardioplegic solutions improves myocardial performance. Prostaglandins Other Lipid Mediat 1998;55:51-65. [CrossRef]

28. Hasturk A, Atalay B, Calisaneller T, Ozdemir O, Oruckaptan H, Altinors N. Analysis of serum pro-inflammatory cytokine levels after rat spinal cord ischemia/reperfusion injury and correlation with tissue damage. Turk Neurosurg 2009;19:353-9. 
DENEYSEL ÇALIŞMA - ÖZET

\section{Siçanlarda bağırsak iskemi-reperfüzyonunun deneysel modelinde iskemi-reperfüzyon hasarının önlenmesinde pentoksifilin ve iloprostun rolü}

\section{Dr. Ugur Abakay, ${ }^{1}$ Dr. Sinan Soylu, ${ }^{1}$ Dr. Sabahattin Göksel, ${ }^{2}$ Dr. Bülent Saraç, ${ }^{3}$ Dr. Zeynep Deniz Şahin İnan, ${ }^{4}$ Dr. Erol Çakmak, ${ }^{5}$ Dr. Özge Korkmaz, ${ }^{2}$ Dr. Atilla Kurt, ${ }^{1}$ Dr. Hüsnü Çağrı Genç ${ }^{1}$}

${ }^{1}$ Cumhuriyet Üniversitesi Tıp Fakültesi, Genel Cerrahi Anabilim Dalı, Sivas

${ }^{2}$ Cumhuriyet Üniversitesi Tıp Fakültesi, Kalp Damar Cerrahisi Anabilim Dalı, Sivas

${ }^{3}$ Cumhuriyet Üniversitesi Tıp Fakültesi, Farmakoloji Anabilim Dalı, Sivas

${ }^{4}$ Cumhuriyet Üniversitesi Tıp Fakültesi, Histoloji Anabilim Dalı, Sivas

${ }^{5}$ Cumhuriyet Üniversitesi Tıp Fakültesi, Gastroenteroloji Anabilim Dalı, Sivas

AMAÇ: İntestinal iskemi-reperfüzyon (IIR) hasarı çoklu organ yetersizliği ve ölüme yol açabilir. Bu çalışmanın amacı, intestinal iskemide reperfüzyon öncesi uygulanan pentoksifilin ve iloprostun etkilerini araştırmaktır.

GEREÇ VE YÖNTEM: 25-300 gr agırlığında 25 Wistar-Albino cinsi sıçan, her bir grupta beş sıçan olacak şekilde beş gruba ayrıldı: Kontrol grubu $(n=5)$, sham grubu ( $n=5 \mathbb{R}$ yok), IR grubu ( $n=5,45 \mathrm{dk}$ iskemi $120 \mathrm{dk}$ reperfüzyon), $I R+P t x$ grubu ( $n=5,45 \mathrm{dk}$ iskemiyi takiben $50 \mathrm{mg} / \mathrm{kg}$ intraperitoneal pentoksifilin ve $120 \mathrm{dk}$ reperfüzyon), IR+IL ( $\mathrm{n}=5,45 \mathrm{dk}$ iskemiyi takiben $2 \mathrm{mcg} / \mathrm{kg}$ intraperitoneal iloprost ve $\mathrm{I} 20 \mathrm{dk}$ reperfüzyon). Deney sonunda ileum örnekleri hemotoksilen-eosin ile boyandı ve histopatolojik olarak Chiu skorlamasına göre değerlendirildi. Izometrik kasılma -gevşeme cevapları organ banyosu kullanılarak kaydedildi.

BULGULAR: Pentoksifilin histopatoljik ve kasılma -gevşeme cevapları açısından anlamlı düzelme sağladı. İloprost reperfüzyon hasarını düzeltmesine rağmen bu düzelme istatistiksel olarak anlamlı değildi.

TARTIŞMA: Bulgularımıza göre pentoksifilin incebağırsak iskemi-reperfüzyon hasarından korumada ümit verici olabilir. Öte yandan, iloprost için daha ileri klinik ve deneysel çalışmalara gereksinim duyulmaktadır.

Anahtar sözcükler: Akut mezenterik iskemi; iloprost; iskemi reperfüzyon hasarı; pentoksiflin.

Ulus Travma Acil Cerrahi Derg 2018;24(5):398-404 doi: 10.5505/tjtes.2018.22227 